by democratic processes with civil authority are entitled to the respectful cooperation of all the people $\ldots$. . . redress of wrongdoing is by established judicial procedure."’o

Whether or not it is either possible or desirable to make the harmony of society depend upon an all-pervading "constituted authority" is highly doubtful. To make it possible, both the legal and the police machinery would have to be expanded tremendously. And the more desirable thing, of course, is to eliminate the racial antagonism by eliminating its cause, and the cause lies in the character of the American people.

The latter is certainly not the function of lawyers as such. But it is the job of lawyers, including military lawyers, to understand thoroughly the end of their profession-i.e., the settlement of disputes in a just and orderly manner-and to know how to achieve that end expeditiously when necessary.

\title{
APPLICATION OF THE WILLIAMS DOCTRINE IN ILLINOIS
}

Prior to his marriage with $\mathrm{W}, \mathrm{H}$ had obtained a Reno divorce. W, seeking a decree of nullity from her marriage with $H$, alleged that her marriage to $\mathrm{H}$ was void because $H$ had not been a bona fide resident of Nevada at the time of obtaining the divorce decree. ${ }^{x}$ After mentioning that the Nevada court had specifically found that $H$ was a bona fide resident, the court held, "Under the ruling in that case [Williams and Hendrix v. North Carolina ${ }^{2}$ ] it is now the law that a divorce decree that is valid in the State of Nevada is also valid in the State of Illinois." Stephens v. Stephens. ${ }^{3}$

In view of the exhaustive treatment elsewhere, further comment on the implications of the Williams case would be superfluous. ${ }^{4}$ The instant case, however, indicates that courts may have some difficulty in the application of the rule enunciated in the Williams case. Most writers agree that the actual holding of the Williams case is that full faith and credit must be accorded to a divorce decree if the bona fide domicile of the party seeking the divorce is within the granting state..$^{5}$

ro Ibid., Part III, at 7 .

I H's wife did not defend the action. In fact, there is no showing that she was notified of the proceedings except by publication in a local Nevada newspaper.

${ }^{2} 317$ U.S. 287 (1942).

349 N.E. (2d) 560 (IIl. App. I943).

${ }_{4}$ Cook, Is Haddock v. Haddock Overruled? I8 Ind. L.J. I65 (1943); Holt, The Bones of Haddock v. Haddock, $4 \mathrm{I}$ Mich. L. Rev. Ior3 (I943); Lorenzen, Haddock v. Haddock Overruled, 52 Yale L.J. 34I (x943); Strahorn and Reiblich, The Haddock Case Overruled-The Future of Interstate Divorce, 7 Md. L. Rev. 29 (1942). This is only a partial list of the comments on the decision.

${ }^{5}$ Cook regards the Williams case as holding that "the new decision on its precise facts is that the state of the plaintiff's bona fide domicile can upon constructive service confer upon its own 
Thus, unless the defendant non-resident entered an appearance questioning the jurisdiction of the forum, ${ }^{6}$ there is nothing in the Williams case which would preclude another state from determining whether or not the divorce-seeking spouse had established a bona fide domicile in the granting state. ${ }^{7}$ Usually as a matter of comity, Illinois courts have accorded recognition to foreign divorce decrees. On occasion, however, the Tllinois courts have refused to give effect to foreign decrees when it appeared that the parties had deceived the granting court as to the jurisdictional facts. ${ }^{8}$ Nothing in the Williams case detracts from the force of these precedents in support of W's contention in the instant case. Since the validity of the Reno decree in Illinois would depend on whether the Reno court had jurisdiction, this was a question which the Mllinois court might properly determine for itself. Nothing in the Williams case seems to preclude a court from so doing.

Furthermore, in Nevada, service of process may be obtained on non-resident defendants by publication. 9 In the instant case, there is no showing that any other medium was employed to inform H's first wife of the pending proceedings. There is a fair likelihood that this ineffective method of giving notice to defendants might be regarded as being a denial of due process. For while this was not presented by the Williams case-the interested parties having actual knowledge of the pending proceedings-the Supreme Court was explicit in stating that a divorce decree, in order to be accorded full faith and credit, must satisfy the requirements of due process. ${ }^{10}$ It would seem that some method reasonably calculated to give actual notice, such as registered mail to the defendant's last abode, should be employed.

There remains the question of whether $W$ is the proper party to question the validity of the Reno divorce. Desiring to protect the validity of existing mar-

domiciliary the privilege and power to acquire a new spouse and that otherStates must recognize this power." Cook, op. cit. supra note 4 , at I77. Cook qualified this interpretation with the assumption that the requirements of due process must be satisfied. Cook, op. cit. supra note 4 , at I77 n. 38. The failure of the Supreme Court to overrule its decision in Bell v. Bell, $18 \mathrm{I}$ U.S. I75 (IgOI) (full faith and credit need not be given a foreign divorce decree if neither party was genuinely domiciled in the granting state) supports this interpretation.

${ }^{6}$ If the defendant entered a special appearance and genuinely contested the jurisdiction of the foreign court, the decision of that court would probably be res judicata. Davis v. Davis, 305 U.S. 32 (I938); see also Chamblin v. Chamblin, 362 Ill. 588, I N.E. (2d) 73 (I936).

7 Fondiller v. Fondiller, 42 N.Y. Supp. (2d) 477 (S.Ct. r943); see In re Bingham's Will, 265 App. Div. 463, 39 N.Y. Supp. (2d) 756 (S.Ct. I943).

${ }^{8}$ See, for example, Jardine v. Jardine, 29x III. App. I52, 9 N.E. (2d) 645 (1937); Janssen v. Janssen, 269 Ill. App. 233 (I93I).

9 Nev. Comp. L. $\S 85^{82}$ (Supp. I93 $\mathrm{I}-4 \mathrm{I}$ ). This section is specifically applicable to divorce actions.

${ }^{10}$ Williams and Hendrix v. North Carolina, 3I7 U.S. 287, 299, 30x, 303 (I942). Publication alone is deemed insufficient notice by Strahorn and Reiblich, op. cit. supra note 4 , at $44-48$; see also the opinion of Judge Dove dissenting in the instant case.

$\therefore$ 
riages, courts have refused on equitable principles to permit a person to question the validity of a prior divorce, if he was the party obtaining the divorce, ${ }^{\mathrm{xI}}$ or was instrumental in its procurement, ${ }^{\mathrm{x} 2}$ or has taken advantage of the decree by remarrying. ${ }^{3}$ It seems well settled, however, that $W$ may contest the validity of H's divorce decree, unless there is a showing that she actively encouraged the proceedings to which she was not a party. ${ }^{14}$

x In re Bingham's Will, 265 App. Div. 463, 39 N.Y. Supp. (2d) 756 (S.Ct. I943); Krause v. Krause, 282 N.Y. 355,26 N.E. (2d) 290 (I940); Guggenheim v. Guggenheim, I89 Ill. App. $x_{4} 6$ (IgI4).

${ }^{12}$ Saul v. Saul, I22 F. (2d) 64 (App. D.C. I94I); Goodloe v. Hawk, Ir3 F. (2d) 753 (App. D.C. I940); Margulies v. Margulies, Io9 N.J. Eq. 39x, I57 Atl. 676 (193r).

${ }^{13}$ Kelsey v. Kelsey, 237 N.Y. 520, I43 N.E. 726 (I923); cf. Marvin v. Foster, 6I Minn. I54, 63 N.W. 484 (r895).

${ }_{14}$ Thus, in Jardine v. Jardine, $29 x$ Ill. App. I52, 9 N.E. (2d) 645 (I937), the court permitted a second wife to annul her marriage on the ground that the divorce her husband had obtained in Nevada was invalid. The result, however, is a bit surprising because there were findings that the second wife helped finance the Nevada expedition of the husband. See also Simmons v. Simmons, Ig F. (2d) 690 (App. D.C. I927). It should be noted, however, that if $W$ prevails in her contention, the effect is to nullify not only her own marriage but possibly the marriage of H's first wife if she has remarried. For a general discussion, see also a note in 8 Univ. Chi. L. Rev. 343 (194I); Rest., Conflict of Laws § II2 (r934). 